\title{
Texts and Artifacts: A Spatial Analysis of Papyri at Karanis
}

\author{
Robert P. Stephan, Stanford University
}

\begin{abstract}
This paper takes a quantitative and spatial analytical approach to the papyri excavated from the Graco-Roman Egyptian town of Karanis. It attempts to accomplish two things. Firstly, it breaks down the descriptive attributes of the papyrological assemblage as a whole, giving a sense of the types of texts, authors, dates and languages involved. The goal of this part of the paper is to overcome the past tendency of publishing individual texts or small archives without their larger context. Secondly, the paper plots the proveniences of papyri from Karanis using a Geographic Information System or GIS. Papyri are used as proxies for socio-economic status and literacy. Plotting the proveniences shows a distinct lack of a single cluster of papyri, revealing instead either several clusters or an even distribution. This suggests the lack of a single wealth or literate center within the town of Karanis. Future studies hope to include both archaeological artifacts and more stratigraphic layers in the GIS spatial analysis.
\end{abstract} $\mid 92$

\section{Introduction}

Since the birth of the academic disciplines of archaeology and papyrology in the late $18^{\text {th }}$ and early $19^{\text {th }}$ centuries, both

\author{
Past Imperfect \\ 16 (2010) | @ | ISSN 1711-053X | elSSN 1718-4487
}


fields have generally grown independently of one another. ${ }^{1}$ This is lamentable because not only both archaeology and papyrology share the same goal of reconstructing the past, but also because these types of evidence can be used in conjunction in a way in which the resultant whole is more than the sum of its parts. By this I mean that the archaeology and papyrology of Greco-Roman Egypt are related in a dialectical manner where the papyrological record can provide important contextual information on how to interpret archaeological remains, and likewise, archaeological context can have a strong influence on the interpretation of the papyri.

A variety of methodologies could be employed in order to integrate archaeological context into the study of papyri. One straightforward way to do this is to analyze the spatial distribution of papyri. The simple but time-consuming task of plotting the findspots of papyri at a given archaeological site allows for the investigation of three potentially insightful questions. First, it has the possibility of revealing any spatial patterning of the distribution of papyri across the site as a whole. Second, it may allow for the identification of specific papyrological archives, or groups of papyri that should be seen as belonging to the same person, family, or organization. Third, it provides a starting point for papyrological distributions to be viewed in relation to archaeological distributions. This can be done on a large scale, for example looking at whether the presence of papyri across the site is often correlated with certain types of artifacts, features, or building structures, or this can be done on a much smaller scale, for example looking at how

I See van Minnen 1993 and van Minnen 1994b for an overview of the history of papyrology.

Past Imperfect

16 (2010) | @ | ISSN 1711-053X | elSSN 1718-4487 
artifactual deposits around particular papyri may illuminate more about the author or reader of the document. ${ }^{2}$

One productive way to deal with this type of spatial analysis for papyri is to use a method and technology that has become a recently growing phenomenon within the field of archaeology, namely the geographic information system (GIS). ${ }^{3}$ Since a GIS functions by integrating geographical data, attribute data, and chronological data, it provides a useful tool for analyzing how a distribution of objects correlates with both geographical features and other objects and how those correlations change over time. In order for this application to be useful in assessing the spatial distribution of papyri and the questions posed above, however, the data set of papyri under consideration must have an archaeological context. As we will see, this is a requirement that is not often met for most of the large collections of papyri that are present today. ${ }^{4}$ Fortunately, the papyri excavated by Francis Kelsey at the Greco-Roman site of Karanis in Egypt have recorded, albeit somewhat problematic, proveniences. ${ }^{5}$

The goal of this paper is to analyze the spatial distribution of papyri from the site of Karanis using a geographic information system. Although this approach has potential utility for assessing all three questions posed above, I will limit the

\footnotetext{
${ }^{2}$ Van Minnen (1994a) attempts this method of inquiry. Its results are summarized later in this paper.

${ }^{3}$ Connolly, 2006 and Wheatley and Gillings, 2002 provide an overview of how this technology has been applied specifically within the field of archaeology. ${ }^{4}$ Several sites currently under excavation, such as Tebtunis, Narmouthis, and Mons Claudianus, may help rectify this problem, although the present number of papyrological finds from these sites have been limited.

${ }^{5}$ See Boak and Peterson, 1931, for the most complete published account of the finds from Karanis.

Past Imperfect

16 (2010) | @ | ISSN 1711-053X | elSSN 1718-4487
} 
scope of this paper primarily to the first of these questions, namely the spatial patterning of the papyrological distributions and their relationship to the architectural remains of the site. The ultimate purpose of course is to relate the spatial papyrological patterns to aspects of society in Greco-Roman Egypt that may be signified by these patterns. For example, how is the literate population distributed throughout Karanis? What role does the veteran population play in creating the papyrological record? These are only some of the various questions that can hopefully be answered. Because highlighting the geographical distribution of different aspects of the papyrological data set can only assess each question, I have constructed a GIS to conduct the analysis which will facilitate the mapping of numerous variables within the data set at Karanis.

\section{Historiographical Context}

In addition to commenting specifically on the spatial distribution of papyri at Karanis, this paper also might be situated within a larger historiographical trend of attempting to bridge the disciplinary divide between archaeology and papyrology. Other studies have gone in depth about the nature and causes of this split. ${ }^{6}$ The general argument provided by Gagos, Gates and Wilburn seems convincing. Essentially, the lack of provenience and spatial context during the development of both archaeology and papyrology led scholars of each field to look at their material in relation to other like materials instead of

\footnotetext{
${ }^{6}$ See especially Gagos, Gates, and Wilburn 2005, and van Minnen 1994b.

Past Imperfect 16 (2010) | @ | ISSN 1711-053X | elSSN 1718-4487
} 
other spatially related materials. ${ }^{7}$ Archaeologists, like Flinders Petrie, focused on developing typologies, while papyrologists used other papyri to fill in the lacunae.

A variety of issues have allowed this divide to persist over the past century, thus limiting the number of spatial approaches to the study of papyri. Environmental factors have played a leading role. The vast majority of documented papyri come from Egypt, with only a few exceptions coming either from unique depositional circumstances (e.g., carbonized papyri from Herculaneum) or from similarly arid climates (e.g., Petra and Dura-Europos in the Near East). ${ }^{8}$ This is not to say that other areas did not make use of the medium, but rather that ecological conditions prevented preservation in most areas of the empire. Other problems arise even within Egypt. Many of our large papyrological collections come from either looted or unrecorded contexts, where the key variable in a plotting a spatial distribution is entirely missing. For those papyri which do possess a secure provenience, differential preservation is again a factor. Since papyri decompose in moist climates, and since many of the residential villages of ancient Egypt were in or very near the Nile Valley, many of the papyri from this region have been destroyed. The majority of texts preserved today come from rubbish pits rather than being discarded in the vicinity of their primary use, which complicates the use of spatial analysis in their interpretation. Finally, papyri from the Faiyum region of Egypt are overly represented compared to Egypt as a whole, and

\footnotetext{
7 This argument expands on a point made by Gagos, Gates, and Wilburn in "Material Culture and Texts of Graeco-Roman Egypt" (2005) pp. 174-5.

8 Bagnall 1995: 10-11. See Cotton, Cockle, and Millar 1995 for a survey of papyri found in the Near East outside of Egypt.

Past Imperfect

16 (2010) | @ | ISSN 1711-053X | elSSN 1718-4487
} 
scholars continue to debate the representative nature of this particular region. ${ }^{9}$

In the past decade attempts have been made to rectify this disparity. Current archaeological excavations are now paying special attention to recording the provenience of papyri. ${ }^{10}$ A recent panel at the 2005 AIA annual meeting specifically addressed this topic, providing case studies in the integration of the two disciplines. ${ }^{11}$ One avenue for future integration of these disciplines may be co-authored works by archaeologists and papyrologists. This has begun to occur in the publication of excavation reports, but also holds potential utility for any type of topical, geographical, or chronological examination of the past.

Three studies attempting to integrate archaeology and papyrology deserve particular mention. The first two take a house-to-house approach, which focuses on using both the papyri and archaeological assemblage from a given house to build a more complete picture of its former inhabitants. Van Minnen pioneered this approach in a 1994 article in which issues of literacy raised from the texts were addressed through the archaeological presence of ink wells and stili within the same level of the house.12 In the second study, by Stephan and Verhoogt in 2005, issues of identity and socioeconomic status

\footnotetext{
${ }^{9}$ See Bagnall and Frier 1994 and Scheidel 2001: 142-3 for problems about the representative nature of the Faiyum papyri.

${ }^{10}$ Examples include Maxwell and Peacock's work at Mons Porphyrites and Mons Claudianus, Pernigotti and Capasso's work at Bakchias, and Sidebotham and Wendrich's work at Berenike.

${ }^{11}$ These are published in the Bulletin of the American Society of Papyrologists 42.

12 Van Minnen 1994a

Past Imperfect

16 (2010) | @ | ISSN 1711-053X | elSSN 1718-4487
} 
raised in the papyri are made clearer through the study of artifacts such as toy swords, faience, and glass. ${ }^{13}$

In the third study that links archaeology and papyrology, Mueller takes a spatial analytical approach to assess migration from areas around the Mediterranean into Egypt. ${ }^{14}$ Her study uses the geographical data from Egyptian census fragments to determine the place of origin of immigrants during the Ptolemaic period. Mapping this using a GIS she provides a clear picture of where the immigrants originated. She goes on to use the GIS to calculate the distances between the cities of origin and Alexandria, the likely port of entry into Egypt. This allows her to test the hypothesis that the number of immigrants to Egypt from a particular area will vary inversely with the city of origin's distance from Egypt (i.e., the further the city of origin, the fewer the immigrants to Egypt). In general this trend holds, although a few anomalies exist, most notably Rome sends more immigrants than it should with regard to its geographical distance from Egypt. Mueller's integration of papyrology and GIS is a good start. It provides a clear and cogent example of how this technology can be used successfully in the field of papyrology, and I believe the potential to use GIS to assess geographical information internal to papyri remains high for future studies as well.

All three of these studies have yielded new insights to the socioeconomic and demographic landscape of Greco-Roman Egypt, yet each have their shortcomings. Alston has criticized the house-to-house approach developed by Van Minnen and further employed by Stephan and Verhoogt by for their limited spatial

${ }^{13}$ Stephan and Verhoogt 2005

${ }^{14}$ Mueller 2005

Past Imperfect

16 (2010) | @ | ISSN 1711-053X | elSSN 1718-4487 
scale and their lack of ability to explain anything other than a single house. ${ }^{15}$ Mueller's study is able to look at macro-level demographic trends using geographical information contained within the texts, but in this type of study the actual physical context of the papyri is of little import. The goal of this paper is to address these critiques using a method that assesses trends at the level of the town while retaining the importance of the papyri's physical provenience.

\section{Case Study: The Spatial Distribution of Papyri at Karanis}

\section{Research Questions}

Through cataloguing and plotting the proveniences of the Karanis papyri I aim to address three main concerns. First, I use my database derived from the University of Michigan's Advanced Papyrological Information System (APIS) online database to assess the overall makeup of my sample of the Karanis papyri. Because papyrological publications usually focus on only one type of document or individual texts, no single overview of the composition of the papyrological collection has been undertaken. This should provide a good overall picture of the Karanis papyri within which topical experts can better frame their work. Second, I use the GIS to assess the general patterning of papyrological distributions across the site. The basic question here is whether visible clusters of high concentrations of papyri exist or whether the papyri are more or less equally distributed across the site. Finally, I discuss how subsets of these papyri

\footnotetext{
${ }^{15}$ Alston 2002: 47

Past Imperfect

16 (2010) | ( ) | ISSN 1711-053X | elSSN 1718-4487
} 
respond to similar questions. I hypothesize, for instance, that literary papyri may follow different spatial patterns than documentary papyri. Likewise, it is possible that papyri authored by men and women may pattern differentially.

In analyzing the spatial patterns of papyri, it is not actually the papyri themselves that are of primary interest to the archaeologist, anthropologist, or historian, but rather the social actors and actions that they represent. One of the primary links here is between papyri and socioeconomic status. Papyrus was not a cheap commodity, and studies have shown that in the $1^{\text {st }}$ century $\mathrm{AD}$ a single sheet of papyrus cost approximately two obols, the equivalent to $\$ 30$ to $\$ 35$ for a sheet of paper today. ${ }^{16}$ It is important, however, to remember that different types of papyri may signify different aspects of society. A tax receipt found in a domestic context, issued by the local government, does not signify a high socioeconomic status in the same way a draft of a private letter would. Papyri may also serve as a proxy for literacy, an important and difficult to access aspect of ancient society. Because of the employment of scribes for both composing and reading texts, it is impossible to say for certain that members of a particular household were literate. ${ }^{17}$ Some types of papyri, such as literary texts, may be more suggestive of literacy than others. ${ }^{18}$ Lastly, certain texts may be used to identify different linguistic, military, or administrative sections of the town through the patterning of different attributes of the papyri. Because of their internal textual content, papyri provide an ideal type of artifact since it can be used to signify such a

\footnotetext{
${ }^{16}$ Harris 1989: 195. Originally from Boak 1933: 98 and Johnson 1936: 306-7.

17 Youtie 1971: 161-76

18 Van Minnen 1994a: 247-9

Past Imperfect

16 (2010) | @ | ISSN 1711-053X | elSSN 1718-4487
} 
variety of people and behaviors. By highlighting different variables within the texts, we have the ability to track these actors and actions through space and time.

\section{Data Set and Methodology}

As previously stated, my data set was derived from the | 101 University of Michigan's APIS online database and focuses on papyri from the site of Karanis. For computational purposes I transferred this information to my own database. A total of 1651 papyri from Karanis were identified and recorded from the database, although this represents only a sample of the 2390 total published papyri from Karanis. Papyri from all levels of the site were recorded for the database and used in the descriptive statistics below, although only those from level B were plotted in the GIS. This limitation was imposed in order to make the study more feasible in terms of time and resources and since one major goal of this paper was to test the general methodology rather than provide a definitive conclusion. For each papyrus 17 variables were recorded. Variables focused primarily on the spatial, chronological, and topical aspects of each papyrus, although language and the author's gender were also included.

The data was attached to the site plans included in Husselman's 1979 architectural overview of Karanis using ArcMAP. ${ }^{19}$ One of the most integral parts to the functionality and utility of a GIS is the database of attribute data that corresponds to the different layers and features. ${ }^{20}$ In this instance the medium

\footnotetext{
${ }^{19}$ Mueller 2005 provides a more in depth overview of the structure and working of a GIS.

${ }^{20}$ Wheatley and Gillings 2002: 23-57

Past Imperfect

16 (2010) | @ | ISSN 1711-053X | elSSN 1718-4487
} 
of inquiry, papyri, posed significant difficulties in the creation of the attribute database. The problem arose from the fact that each house (the feature) contains multiple papyri (the object of analysis), but then each papyrus in turn contains a series of related data (e.g., data, language, genre). It is important that these variables are kept internally consistent in order to be able to ask questions such as, "How many papyri are there that are both Greek and from the 2nd century?" The answer to this problem may be to create a one-to-many database, which while straightforward in actual database software (e.g., Microsoft Access or Filemaker), proved to be difficult using ArcMAP's geodatabase. ${ }^{21}$ To address this problem aggregate numbers of the information contained in each papyrus were entered for each house. The database allowed for the query of the following categories: total number of papyri, genre (literary, documentary), language (Greek, Latin, Coptic, Demotic), date (Ptolemaic, $1^{\text {st }}, 2^{\text {nd }} 3^{\text {rd }}, 4^{\text {th }}, 5^{\text {th }}, 6^{\text {th }}$ centuries AD), and a cross genre aggregate that I used as a proxy for literacy (literary plus epistolary papyri). Thus in the end one could search for the total number of Greek papyri or the total number of $2^{\text {nd }}$ century papyri from a house, but one could not search for the total number of papyri that were both Greek and $2^{\text {nd }}$ century.

\section{Context}

Karanis, associated with modern Kom Aushim, was a town located on the northeastern outskirts of the Faiyum region

\footnotetext{
${ }^{21}$ Conolly and Lake 2006: 51-60

Past Imperfect 16 (2010) | @ | ISSN 1711-053X | elSSN 1718-4487
} 
of Egypt. ${ }^{22}$ It was founded by Ptolemy II Philadelphus in the $3^{\text {rd }}$ century BC and remained occupied for at least 600 years until the late $5^{\text {th }}$ or early $6^{\text {th }}$ century AD. ${ }^{23}$ The site peaked in terms of population from the $2^{\text {nd }}$ to $4^{\text {th }}$ centuries $A D$ as Roman administration continued the land reclamation and irrigation projects begun by the Ptolemies. ${ }^{24}$ Increasingly arid climates in the Late Antique period led to the evaporation of Lake Moeris, the central source of irrigation in the Faiyum, and by the early $6^{\text {th }}$ century the desert had reclaimed Karanis.

In many ways Karanis was a standard Egyptian town during the Greco-Roman period. Karanis was not a cosmopolitan metropolis like Alexandria, but it was by no means a small village. 25 Working from papyrological tax documents, its population can be judged to have fluctuated between approximately 3,300 and 1,900 during the $2^{\text {nd }}$ century, ${ }^{26}$ which is roughly equivalent to its neighboring Faiyum towns. ${ }^{27} \mathrm{~A}$ mix of Greeks, Romans, and native Egyptians would have populated Karanis, like most towns of any significant size. Once again using papyrological tax documents as evidence, Alston demonstrates that 14 percent of the population had Latin names. ${ }^{28}$ Although this does not mean that all these people were Romans in the strict sense, it is a comparatively higher number than other

\footnotetext{
22 See Husselman 1979 and Gazda and Wilfong (eds.) 2005 for an overview of Karanis.

${ }^{23}$ Husselman 1979: 7-10

${ }^{24}$ Westerman 1917: 426-30

${ }^{25}$ See Bagnall and Frier 1994 and Scheidel 2001: 142-3 for problems about the representative nature of the Faiyum papyri.

${ }^{26}$ Boak 1955 . The 3,300 number comes from the early $2^{\text {nd }}$ century. The 1,900 number comes from the later $2^{\text {nd }}$ century after the Antonine plague.

${ }^{27}$ Boak 1926: 360-2. Bagnall and Frier 1994 provide a good overview of general demographic trends in Egypt during the Roman period.

${ }^{28}$ Alston 1995: 123

Past Imperfect

16 (2010) | @ | ISSN 1711-053X | elSSN 1718-4487
} 
nearby towns, and suggests a higher rate of settlement for veteran soldiers of the Roman armies stationed in Egypt. Since the Roman army was one of the institutions most responsible for the development of literacy, and since it has been shown that Karanis has a higher level of veterans than most Egyptian towns, it seems possible that this high level of veteran settlement is responsible for the large quantities of papyrus found at Karanis. Unfortunately, the lack of sites excavated on a similar scale prevents any type of inter-site quantitative comparison. Also, despite the focus on veterans and their influence in the construction of the papyrological record, it must be stressed that they were still the vast minority in this and almost all Egyptian towns.

The study of Karanis began in the late 19th century with "excavations" first led by Flinders Petrie and subsequently, Bernard Grenfell and Arthur Hunt. ${ }^{29}$ These were excavations only in the sense that they removed things from the ground. Husselman states that it was "simply a search for papyri,30" and no attempt was made to even collect archaeological remains, much less document them. Under Francis Kelsey, the University of Michigan's 1924-1935 excavations at Karanis worked to rectify the disparity in the types of evidence collected. As previously stated, they were some of the earliest large-scale excavations to excavate stratigraphically and record the proveniences of artifacts and papyri alike. Despite Kelsey's foresight in predicting that the integration of these two strands of evidence would yield the best reconstruction of the past, the stratigraphic excavations were still crude by modern

29 Petrie 1892 and Grenfell, Hunt, and Hogarth 1900 respectively.

30 Husselman 1979: 1

Past Imperfect

16 (2010) | @ | ISSN 1711-053X | elSSN 1718-4487 
standards. ${ }^{31}$ The site was split into five different levels, A through $\mathrm{E}$, with $\mathrm{A}$ being the most recent and $\mathrm{E}$ being the oldest. These levels were used across the entire site, and much of the detailed data about individual house abandonment and reoccupation must have been lost. Nonetheless records still attribute papyri to particular houses, and even if the stratigraphic information is flawed, horizontal distribution patterns still hold promise. Kelsey's death in 1927 seemingly brought with it the end of an interdisciplinary methodology. Since then numerous archaeological $^{32}$ and papyrological ${ }^{33}$ studies have been undertaken on the material from the site, each limiting references to the other to merely a few lines. Only recently with the studies described above has the integration of these two data types begun once again. ${ }^{34}$

When discussing papyri and context one must go beyond the historical setting of the site. A spatial analysis of the distribution of papyri is based upon the assumption that the papyri are deposited near their location of primary use. As discussed above, most papyri in Greco-Roman Egypt come from rubbish pits, and thus the spatial patterns resulting from a GIS analysis where this is the case would not speak to issues of literacy or socioeconomic status, but rather issues of waste management. Karanis again seems to be somewhat unique. Some

${ }^{31}$ Gagos, Gates, and Wilburn 2005: 179-80. Originally from Ann Arbor Daily News May 26, 1934.

${ }^{32}$ Allen 1985 (terracotta figurines); Gazda 1978 (sculptures); Haatvedt and Peterson 1964 (coins); Harden 1936 (glass); Johnson 1981 (pottery); Shier 1978 (terracotta lamps)

33 Youtie, Schuman, and Pearl 1936-39, Youtie and Pearl 1944, Youtie 1951, and Husselman 1971

34 The Kelsey Museum is currently working on a database uniting both their archaeological and papyrological collections from Karanis.

Past Imperfect

16 (2010) | @ | ISSN 1711-053X | elSSN 1718-4487 
archives, such as that of Tiberianus, seem to have been left in situ, while many other papyri seem to have been discarded in adjacent, abandoned houses rather than in set rubbish pits. ${ }^{35}$ Thus even if certain papyri did not originate in the house in which they were found, it is likely that they were in use in close proximity to where they were found. A large scale, town-wide study should still illuminate distinct patterns if they exist.

\section{Analysis and Results}

Analysis of the Karanis papyri essentially produced two categories of results, one focused on the database created from all papyri across all periods, and the other focused on the GIS created from the papyri attributed to stratigraphic level B. First and foremost, a chronological assessment of the papyri shows a peak during the $1^{\text {st }}$ to $4^{\text {th }}$ centuries AD (Figure 1). This coincides with the standard account produced from the archaeological record of Karanis' prosperity during this period. ${ }^{36}$ Because of this similar stories told by both archaeology and papyrology, it is likely that this is a meaningful peak in terms of the sites history, rather than an anomalous peak derived from preferences in writing habits with the MacMullen's epigraphic habit. ${ }^{37}$ When they are grouped by stratigraphic levels, the papyi show similar trends (Figure 2). The overwhelming majority of those that were attributed to a stratigraphic layer come from the B and C levels (97 percent). With the $\mathrm{C}$ level corresponding roughly to the $1^{\text {st }}$ to

\footnotetext{
${ }^{35}$ Stephan and Verhoogt 2005 for a discussion of the Tiberianus archive, which was deposited under the stairs of house B167.

${ }^{36}$ Husselman 1979

${ }^{37}$ MacMullen 1982, Meyer 1990.

Past Imperfect

16 (2010) | @ | ISSN 1711-053X | elSSN 1718-4487
} 
mid $2^{\text {nd }}$ centuries $\mathrm{AD}$ and the $\mathrm{B}$ level representing approximately the mid $2^{\text {nd }}$ to $3^{\text {rd }}$ centuries $\mathrm{AD}$, this picture meshes well with the chronological distribution of papyri. The only disparity is the large number of $4^{\text {th }}$ century papyri in the chronological distribution and the lack of level A papyri (dating from the $3^{\text {rd }}$ to $5^{\text {th }}$ centuries $A D$ ) in the stratigraphic distribution. I would hypothesize that this disparity arises from the fact that a large portion of the papyri from unknown stratigraphic levels $(n=703)$ comes from level A. It is possible that this is due to them having been unearthed during an early period in the excavation when house numbers had been assigned but before stratigraphic levels had been assigned. ${ }^{38}$ This idea is supported by the fact that none of the over 300 papyri excavated during the first two years of the excavation have stratigraphic levels attributed to them. Since the layering system at Karanis went from A (the topmost level) to E (the bottommost level), it seems logical that many of the papyri unearthed in the early years would have been close to ground level and thus been contained within stratigraphic level A. A distributional breakdown by year of excavation shows that papyri continued to be unearthed throughout the excavation with a slight peak in 1928 (Figure 3).

Textual information internal to the individual papyri can also be quantified in order to provide a clearer understanding of exactly which social groups within Karanis were creating (or consuming) these documents. For example, of the documents which have a named author $(n=255) 87$ percent are men, 11 percent are women, and 3 percent are co-authored by both men and women (Figure 4). Scribal prevalence prevents drawing

${ }^{38}$ Gagos, Gates, and Wilburn 2005

Past Imperfect

16 (2010) | @ | ISSN 1711-053X | elSSN 1718-4487 
exact conclusions about literacy in this instance and about who actually inked the documents. Nonetheless this still provides important information about who had access to textual creation, and the numbers link up well with general assessments of gender ratios of literacy. ${ }^{39}$ Linguistically, Greek papyri dominate the collection consisting of 98 percent of the total published papyri (Figure 5). It is unlikely, however, that this accurately represents the overwhelming dominance of Greek as the written language. Publication of Greek and Latin texts is far more common than the publication of Coptic and Demotic texts. Greek may have been the standard administrative and possibly even the nongovernmental language of choice. However, it is almost certain that Coptic and Demotic texts are severely underrepresented in this study.

A distributional breakdown of the content of the papyri also reveals what the people of Karanis wrote about. This study does not attempt too much depth in this area, but one general distinction that can be made is between documentary and literary papyri. Documentary papyri are for the most part private and include everything from tax rolls to sales receipts to private letters. Literary papyri are those texts, like Homer's Iliad, that are made for public consumption. At Karanis, as with most sites, documentary papyri form the majority of the collection with 95 percent of the total texts $(n=1650)$ (Figure 6). This seems to be clear evidence that above all, writing was a utilitarian tool rather than a pleasurable activity. These documentary papyri can further be broken down into specific topical categories (Figure 7). Of the eight categories, including literary papyri, which I

${ }^{39}$ Pomeroy 1988

Past Imperfect

16 (2010) | @ | ISSN 1711-053X | elSSN 1718-4487 
created, receipts from taxes and sales rank first followed by letters, literature, and accounts. These categories are in a sense arbitrary and only made possible by grouping texts with sometimes significant differences. While it may not be possible to draw definite conclusions from this data, it is at least suggestive of the breadth of topics undertaken in writing as well as the prevalence of some more than others.

It is difficult to tell how these distributions fit within the larger picture of Greco-Roman Egypt. In the same way that this spatial distribution analysis has not been done before for Karanis, it has also not been done at any other sites across GrecoRoman Egypt. This is due primarily to the lack of sites with large collections of papyri with known provenience. This data, besides illuminating something about the text-creating/consuming portion of the population at Karanis, should serve as point of comparison for future quantitative studies of papyrological collections. As the number of case studies grows, generalizations concerning Egypt during the Greco-Roman period should become more accurate as argumentation becomes more quantitative and less anecdotal.

The spatial patterning of the Karanis papyri attributed to stratigraphic level B was analyzed using a GIS. One of the primary questions under consideration was the extent to which patterns existed in the spatial distribution of the papyrological proveniences. Papyrological clustering is important since it serves as a proxy for a variety of aspects of ancient Greco-Roman Egyptian society. If the papyri were all concentrated in a single cluster within a limited geographic range, it may be indicative of a literate, wealthy section of the city. If, on the other hand, papyri were evenly distributed across the city it may be evidence for

\section{Past Imperfect}

16 (2010) | @ | ISSN 1711-053X | elSSN 1718-4487 
more of a diffusion of literacy and wealth. Plotting all the proveniences of papyri from stratigraphic level B at Karanis provides some interesting results (Figure 8). The most obvious result is that there is definitely no single, large cluster of papyri. Although the destruction of a large portion of the site by the sebbakhin makes spatial analysis somewhat difficult, it appears as though a few papyrological centers exist, and these are spread throughout all portions of the city. As one moves away from these cores, the concentrations of papyri drop off slightly (Figure 9). Thus the answer to this first question is that while there may not be a single center of high papyrological concentrations, there may be several centers of high papyrological concentrations. This does not negate them acting as a proxy for a high socioeconomic status. In fact, the top eight houses in terms of papyri have an average area of $154 \mathrm{~m}^{2}$, over twice the average for houses in Egypt during Greco-Roman period.40 The main point, however, is that these areas are distributed throughout the city rather than clustered in an isolated enclave.

The patterns above are generated primarily by high numbers of men writing papyri in the Greek language. Patterning in some variables, if they do not occur in a large number of cases, may be lost as the most common types of cases largely determine the spatial distribution patterns. By isolating only the papyri authored by women and plotting their distribution, it is easier to assess if any patterning exists according to gender (Figure 10). The findspots of female-authored papyri are spread throughout the city in much the same way as the papyri as a whole. Because the total number of papyri authored by women in stratigraphic

${ }^{40}$ Alston 2002, Stephan (unpubl.): 37

Past Imperfect

16 (2010) | @ | ISSN 1711-053X | elSSN 1718-4487 
level $B$ is so low $(n=15)$, it is impossible to determine whether this is indicative of any real pattern. It is worth noting, however, that no houses consisted solely of women's papyri. Linguistic patterns may also be lost due to the vast majority of Greek papyri. Plotting only the non-Greek and multilingual papyri (i.e., Coptic, Demotic, Latin, and multilingual), an interesting pattern emerges (Figure 11). A cluster appears to form in the eastern center of the town. This is the only variable which seems to cause papyri to cluster. While it is easy to hypothesize that this was some ethnic quarter of the town, the sample size is so low $(n=19)$ that no real conclusions can be drawn. Although sample size is a problem for non-Greek languages in this study, it has a potential solution if increasing numbers of Coptic and Demotic papyri begin to be published.

The difficulties in assessing literacy rates for ancient societies have been thoroughly documented. ${ }^{41}$ In dealing with any type of chronological or spatial distribution of texts, however, it is too important of an aspect of ancient society to completely neglect. The focus for this study is not the literacy rate, but rather the spatial distribution of literate households within the town. As stated above, different types of texts can serve as proxies for different types of social behaviors. I would argue that although it may be impossible to identify literate households with 100 percent certainty, and although many types of papyri clearly do not indicate any type of literacy within the household (e.g., tax receipts), some papyrological genres may be able to serve as approximate proxies for literacy.

${ }^{41}$ See Bowman 1991: 119-23 for a discussion of the difficulties involved in using different types of evidence as proxies for literacy.

Past Imperfect

16 (2010) | @ | ISSN 1711-053X | elSSN 1718-4487 
The most applicable proxy, in my opinion, is the genre of literary papyri. Since possession of these texts would have been for education or enjoyment, it seems likely to me that they, more than any other type of text, would signal that the household, or some part of it, had attained a certain level of literacy. Plotting the distribution of literary papyri reveals a pattern fairly similar to that of the distribution of the papyrological collection as a whole (Figure 12). No single literate sector of the city is evident. Rather, the several households that contain literary papyri are spread throughout the town. Since the number of literary papyri in stratigraphic level B was rather small $(n=26)$, I have also created a multivariate proxy that I believe may work well as an index of literacy. To do this I have combined literary papyri with private letters and plotted their combined distribution (Figure 13). Private letters were chosen as the second least utilitarian category of texts. Once again, the distribution pattern echoes that of the entire collection of papyri from stratigraphic level B. No single cluster is apparent, and areas of high concentrations are distributed throughout the city.

One additional piece of evidence that supports the use of these variables as proxies for literacy is their percentage of presence. Literary papyri are present in 11 of the 197 houses (5.6 percent) in stratigraphic level B at Karanis, and including private letters increases their presence to 13 of the 197 houses (6.6 percent). These rates coincide precisely within Harris' estimation for a 5 - 10 percent literacy rate throughout the Roman world. 42

\footnotetext{
${ }^{42}$ Harris 1989: 272

Past Imperfect 16 (2010) | @ | ISSN 1711-053X | elSSN 1718-4487
} 
Paleographical date was the final variable analyzed in terms of its spatial distribution. The primary questions under consideration with this variable were if and how papyrological distributions changed over time. Since only one stratigraphic level was examined in this study, the temporal scale was slightly limited, and much fewer papyri were attributed to the very early and late centuries of occupation in stratigraphic level B. Nonetheless it is worth a brief investigation. In plotting the papyri by the century when they were written, the recurrent theme of the lack of a singular high concentration is apparent (Figure 14). At no point throughout any of the first six centuries $\mathrm{AD}$ does this pattern change in a considerable range. Even in the $1^{\text {st }}$ c. $A D$, which, with only four houses with papyri, was one of the least well represented, the papyri are distributed across the entire city.

\section{Conclusions and Future Directions}

The conclusions that can be drawn from this study are simple yet meaningful. Spatial assessment of the papyri using a GIS has shown that papyrological proveniences at Karanis definitely do not cluster in a single, highly concentrated area. Rather they seem to be distributed throughout the town, with multiple areas of high concentrations. This pattern is recurrent when the proveniences are plotted in accordance with a variety of variables including gender of the author, genre, and date of composition. The only variable to not conform to this spatial pattern was that of linguistics, which showed a concentration in the eastern central portion of the site. It is quite possible, however, that this is due to a small sample size rather than a 
special ethnic neighborhood. By using the papyri as proxies for social actors and actions, they can provide us with information about the spatial distribution of socioeconomic statuses and literacy throughout the town. The wide range of distribution of papyri suggests the possible lack of a single wealthy and/or literate neighborhood in Karanis, and classes were likely to have been somewhat geographically integrated.

While these findings are important additions to our knowledge of social demographics and dynamics in ancient cities, future studies in this area have the potential to contextualize these conclusions as well as answer new questions. One obvious step that can be taken is to undertake a study similar to this for the rest of stratigraphic levels at Karanis. While the spatial patterns produced here seem secure for the B level, only further analysis will be able to tell whether this is a normative or anomalous pattern. Analyses of papyrological distributions at other Greco-Roman Egyptian sites would provide important contextual information for this study, and current projects such as those at Tebtunis, Narmouthis, Mons Claudianus, Bakchias, and Berenike may provide that opportunity if the number of papyrological finds increase. This would help answer the question of whether the patterns found here may be considered typical of towns during this period or whether Karanis is a unique situation. Finally, and perhaps most importantly, this type of GIS study could be expanded to include all artifactual remains in addition to the papyri. From this it would be possible to identify the types of artifacts with which papyri were most often found. Archaeological remains such as inkwells, wax tablets, and stili, could also be used as important additional evidence in the study of literacy rates and 
distributions. This integration is already underway at the Kelsey Museum for the site of Karanis and promises to yield exciting new results.

This study has attempted to show the benefits that can be gained from integrating the disciplines and methodologies of archaeology, papyrology and GIS. It is hopefully only a matter of time before these areas become further entangled, and through this process, new insights into the past occur.

Maps, Figure and Charts

Figure 1

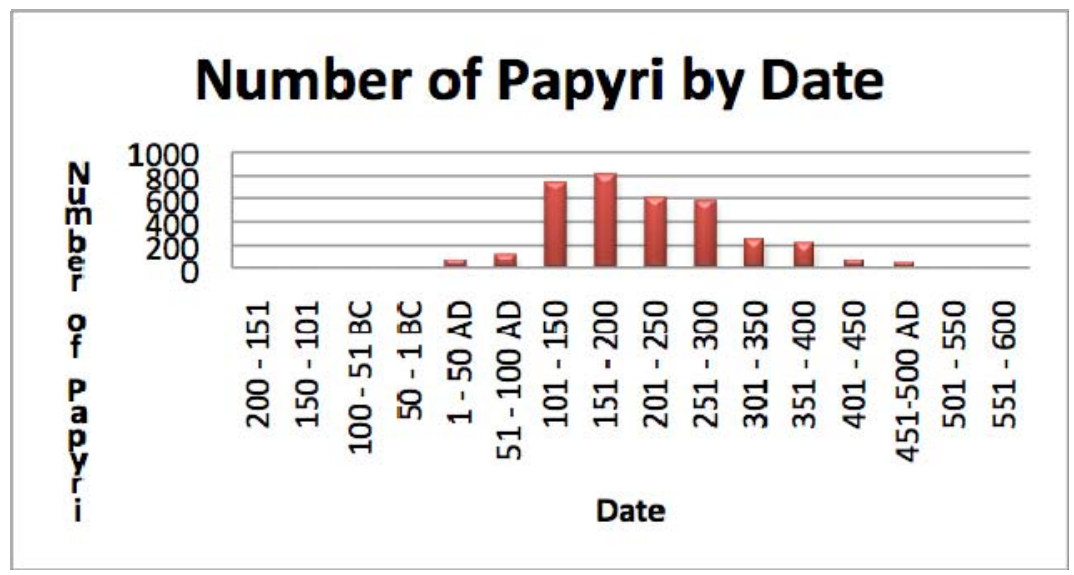

Figure 2 


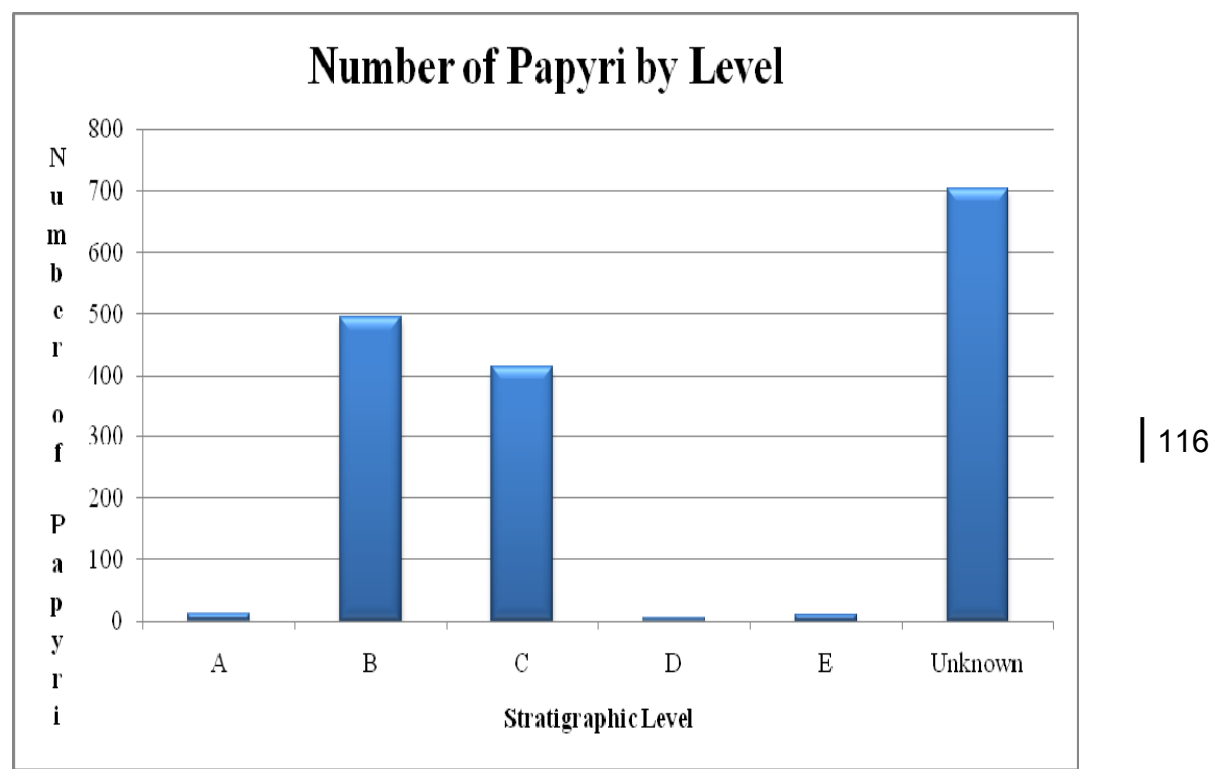

Figure 3

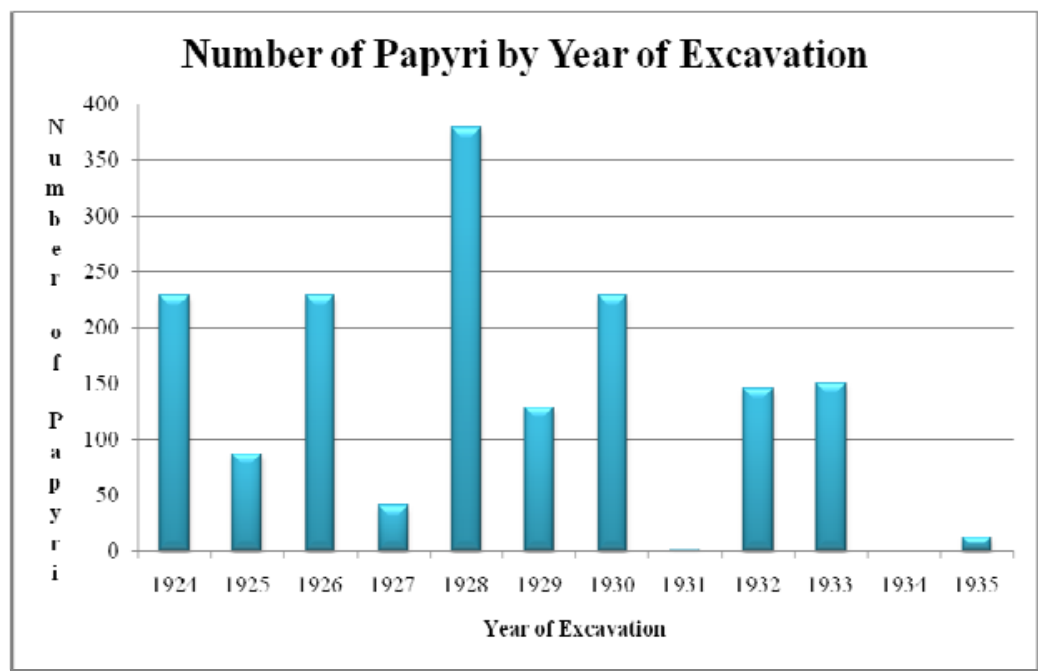

Figure 4

Past Imperfect

16 (2010) | @ | ISSN 1711-053X | elSSN 1718-4487 


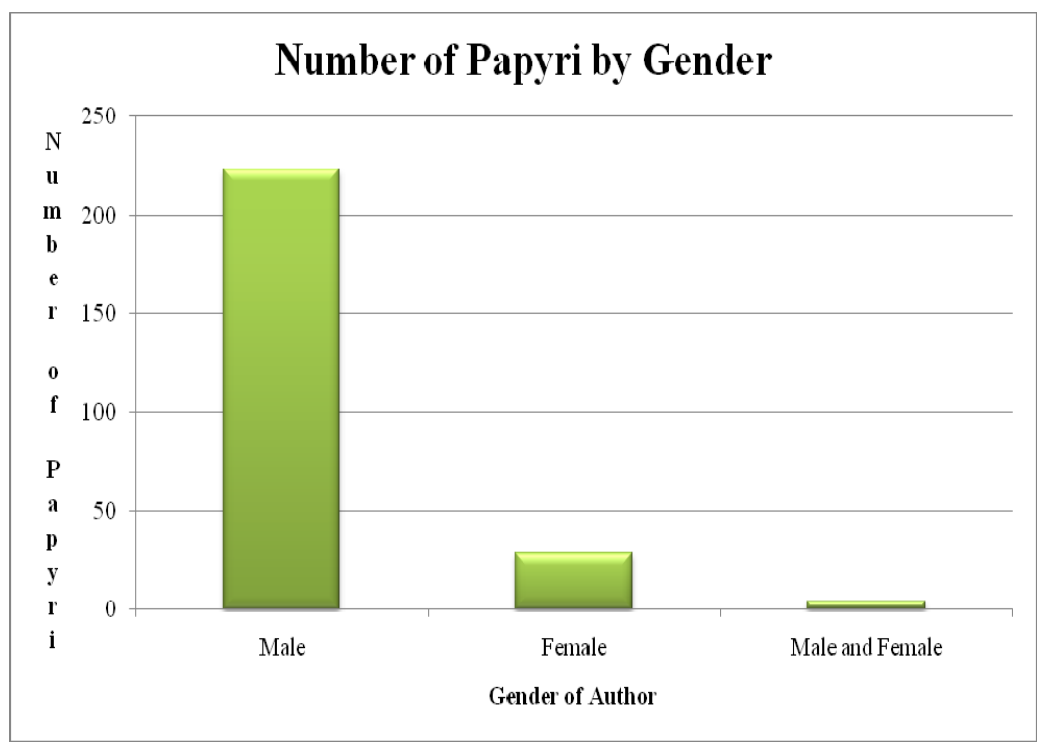

| 117

Figure 5

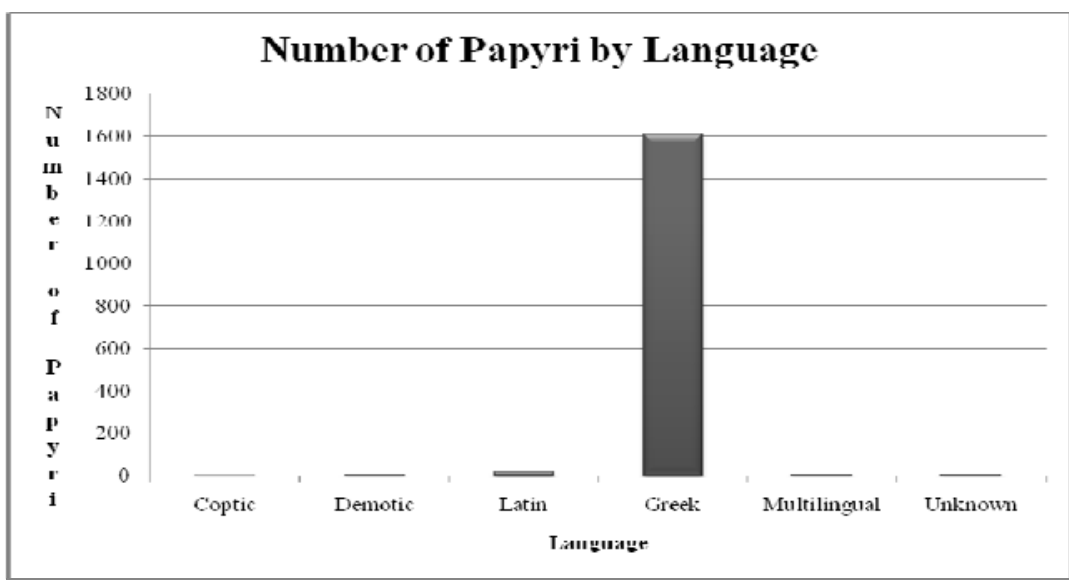

Past Imperfect

16 (2010) | @ | ISSN 1711-053X | elSSN 1718-4487 
Figure 6

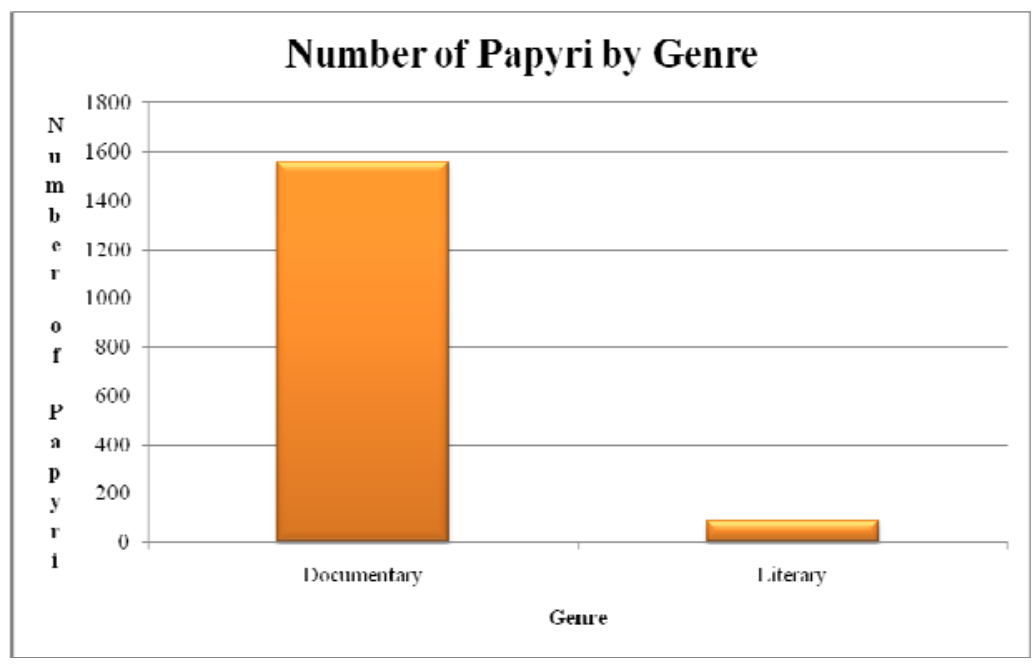

Figure 7

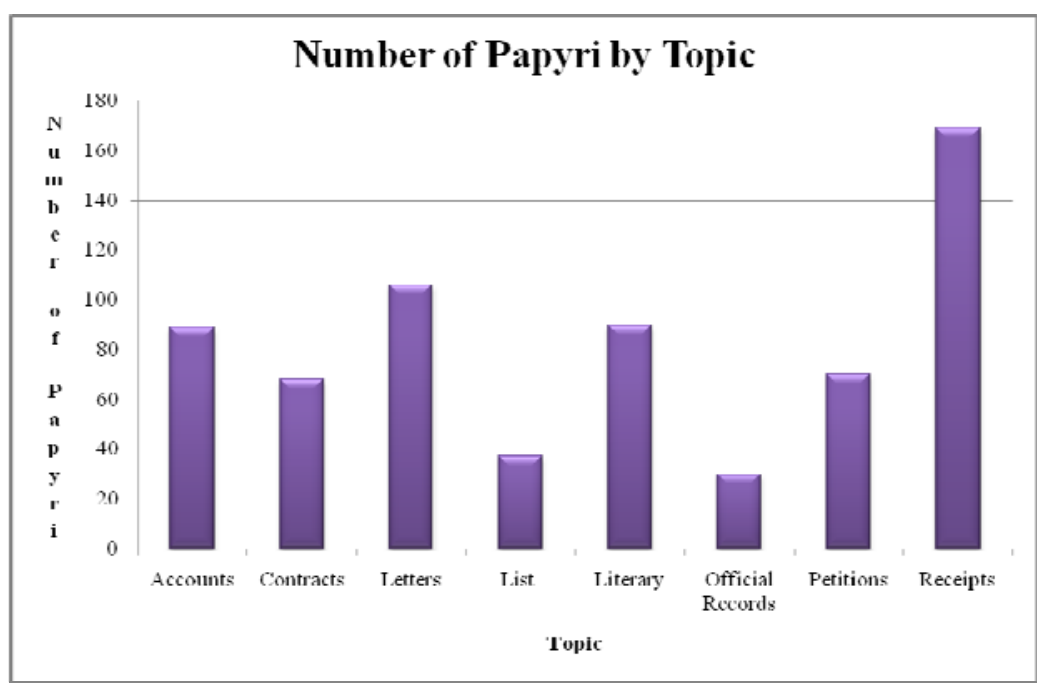

Past Imperfect

16 (2010) | @ | ISSN 1711-053X | elSSN 1718-4487 
Figure 8

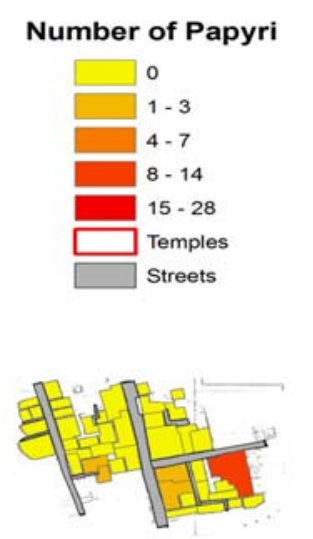

盟照

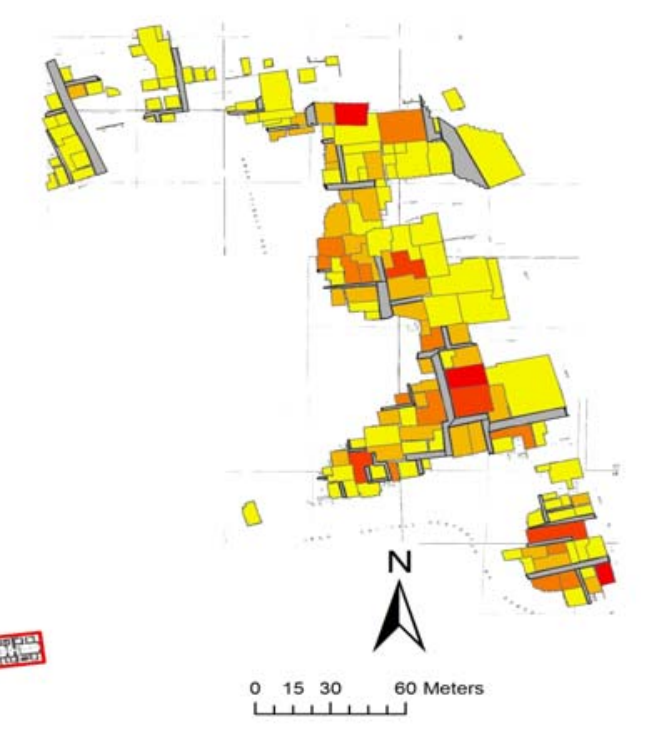

Distribution of all papyri at Karanis from stratigraphic level $B$ 
Figure 9

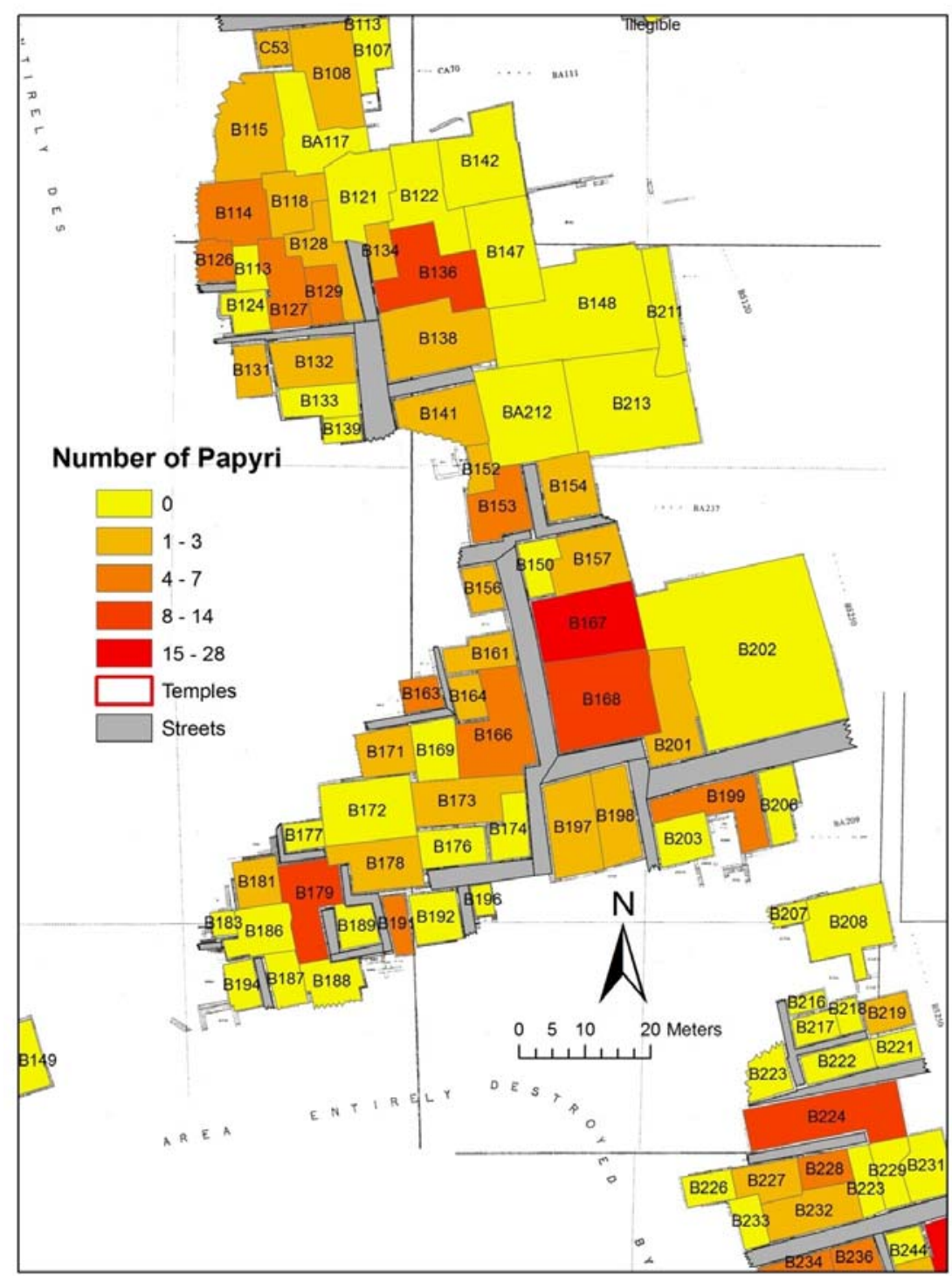

| 120

Close up of the central portion of Karanis showing a possible steady decline in papyrologicalquantities as the distance from multiple core areas increases

Past Imperfect

16 (2010) | @ | ISSN 1711-053X | elSSN 1718-4487 
Figure 10
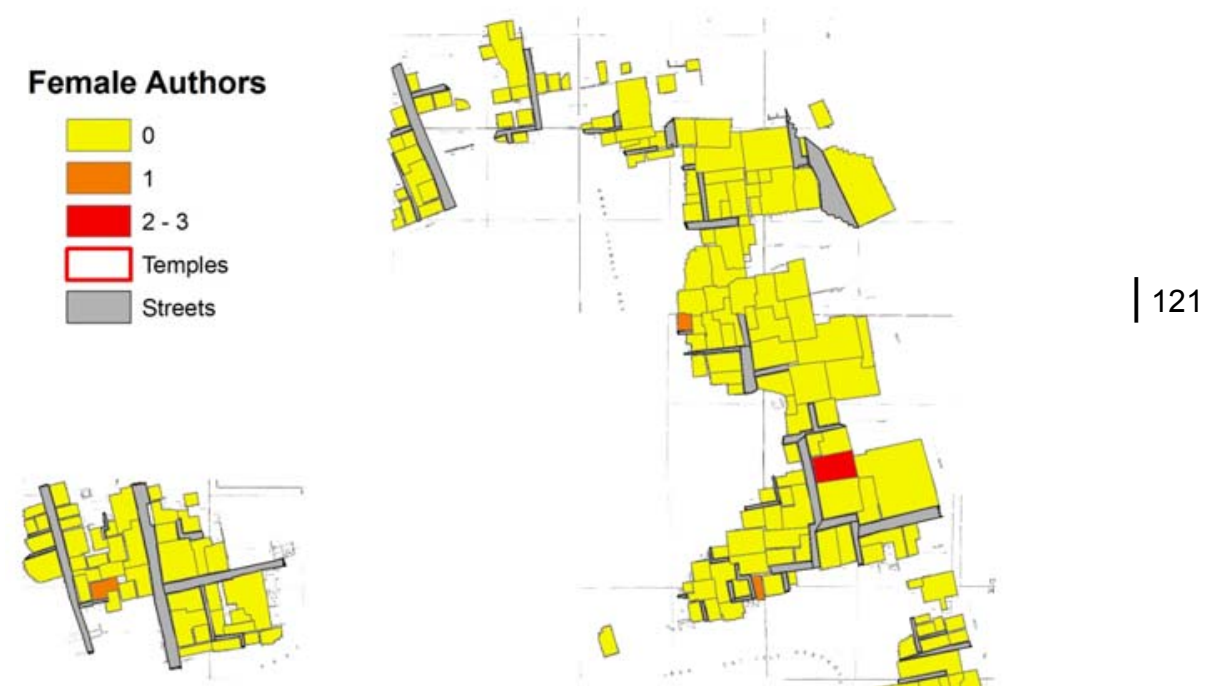

躡

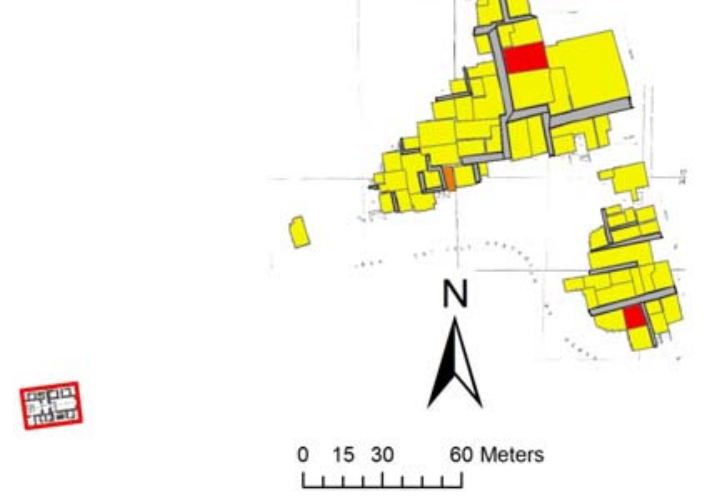

Number and location of papyri authored by women 
Figure 11

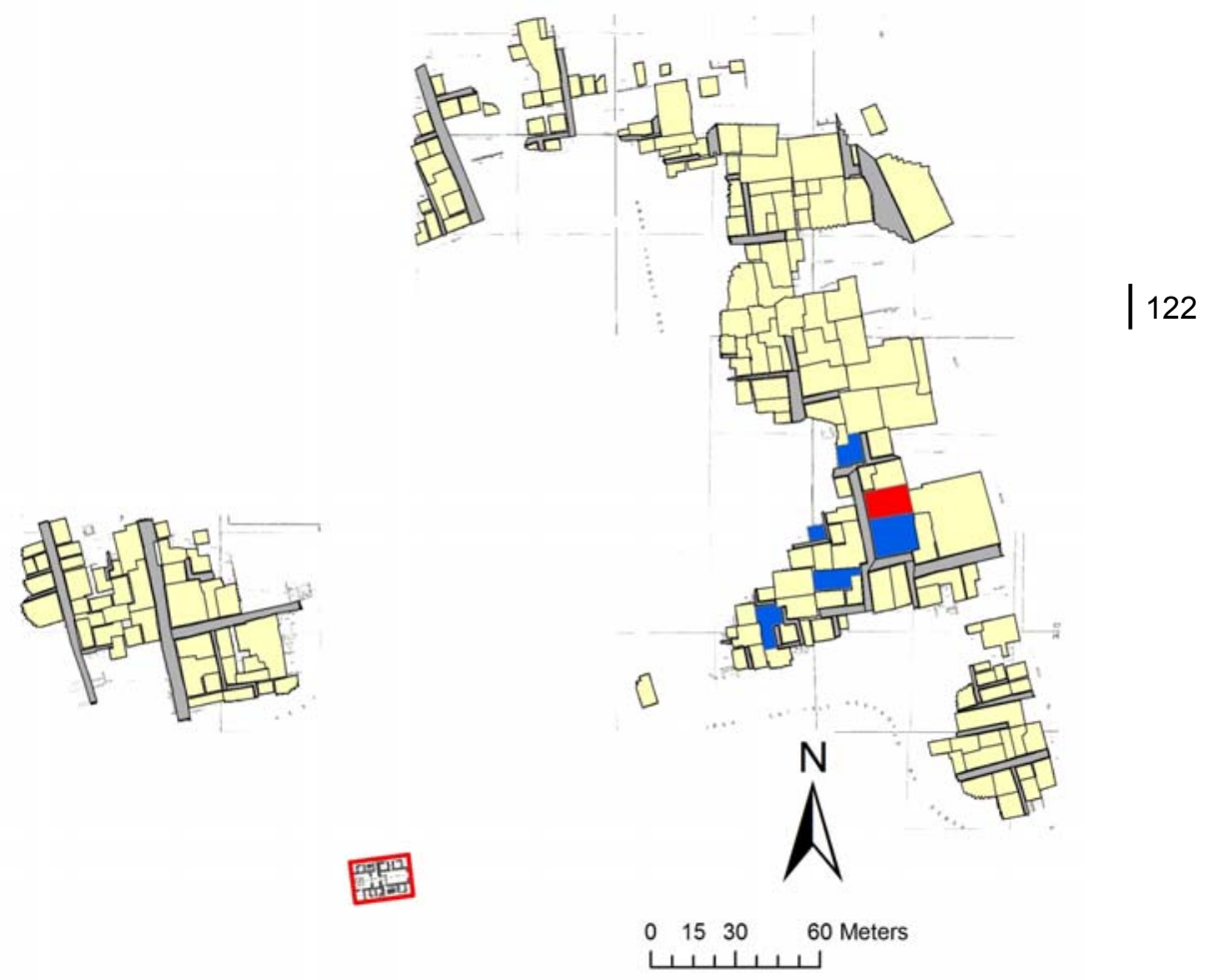

Locations of non-Greek papyri; Demotic and Coptic are in blue, Latin is in red 
Figure 12
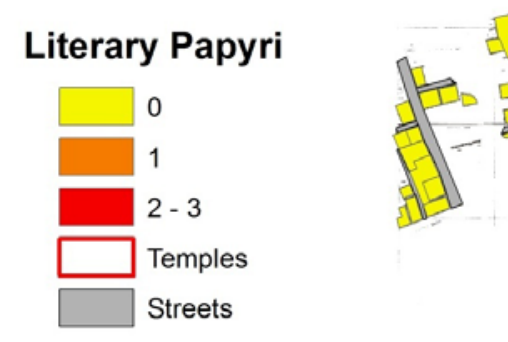

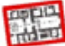
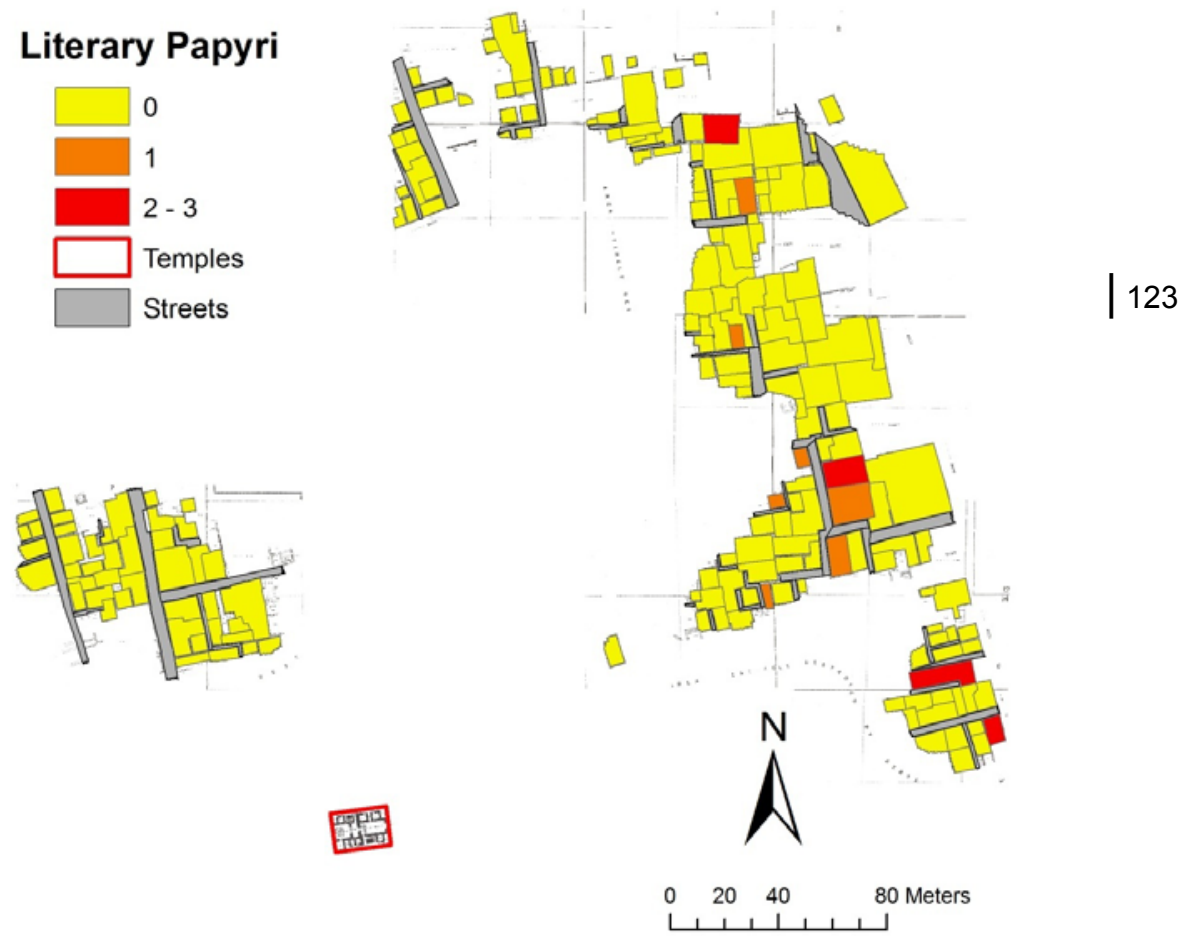

Distribution of literary papyri at Karanis, stratigraphic level B 
Figure 13

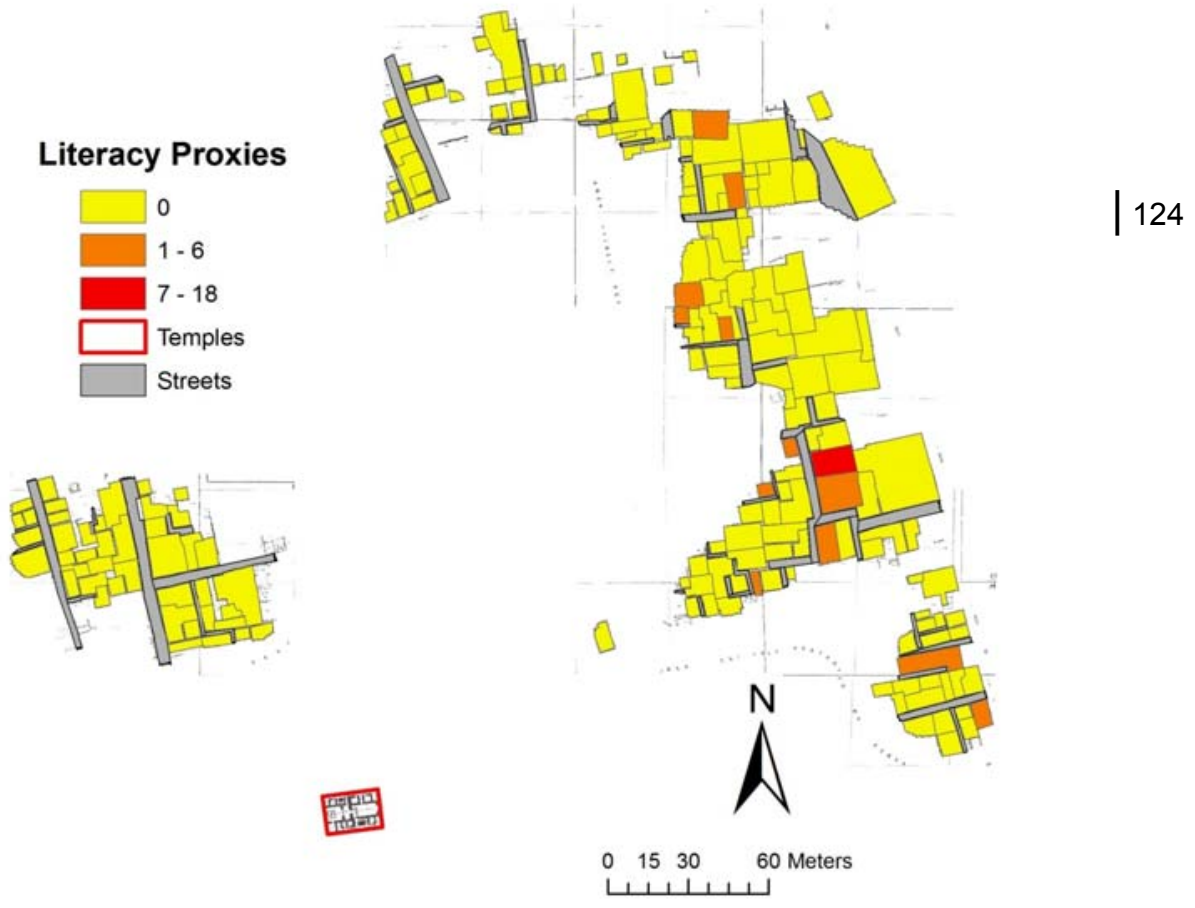

Location and counts for literary and epistolary papyri, a hypothesized proxy for literacy 
Figure 14
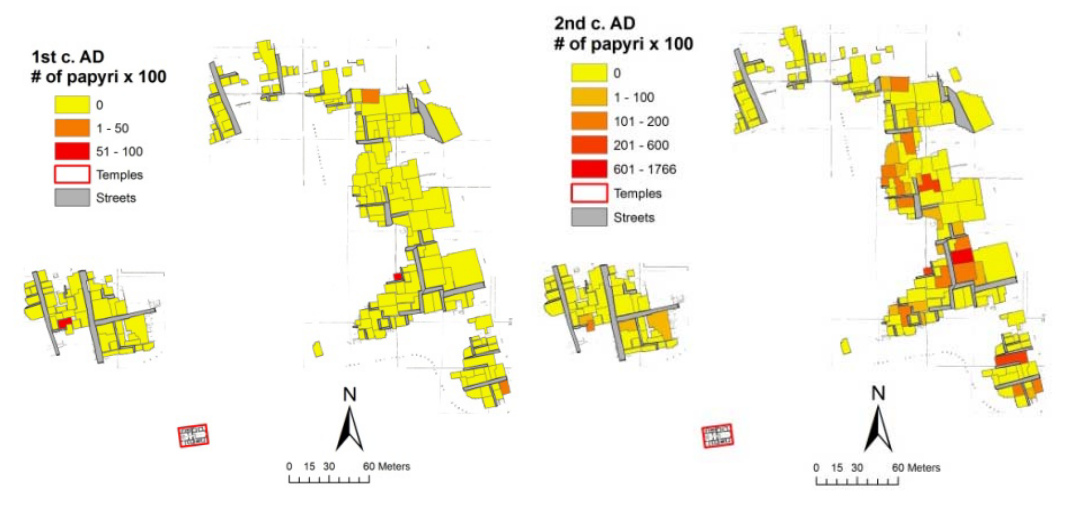

| 125
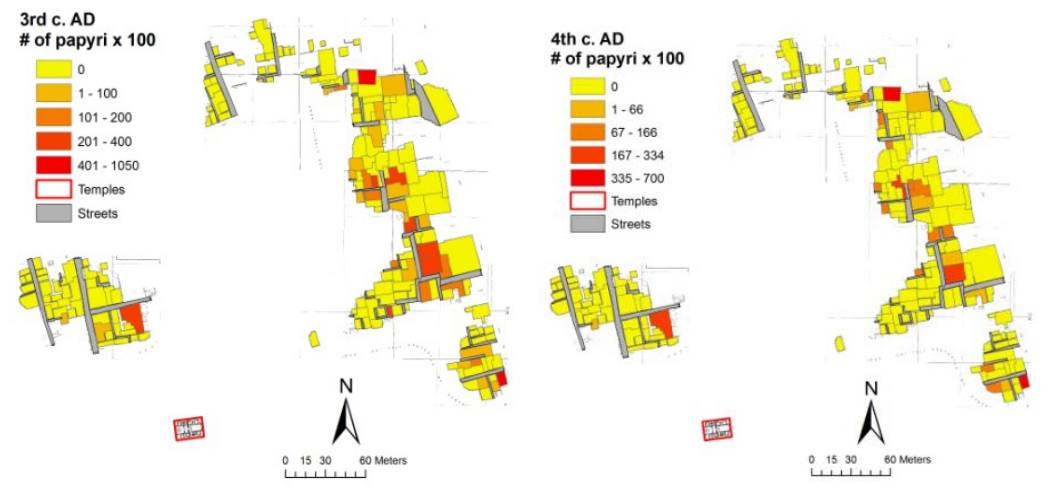

Past Imperfect

16 (2010) | @ | ISSN 1711-053X | elSSN 1718-4487 


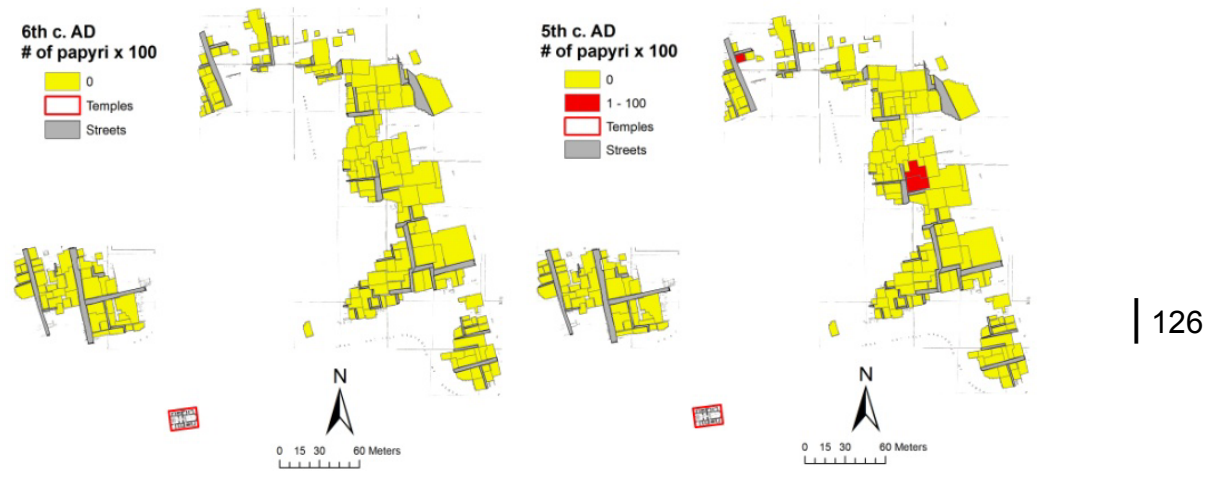

Change in papyrological distributions over time in stratigraphic level B at Karanis 


\section{Bibliography}

Allen, M.L. (1985) The Terracotta Figurines from Karanis: A Study of Technique, Style, and Chronology of Fayoumic Coroplastics 1-2, Ann Arbor.

Alston, R.A. (1995) Soldier and Society in Roman Egypt: A Social History, London and New York.

Alston, R.A. (2002) The City in Roman and Byzantine Egypt, London and New York.

Bagnall, R. (1995) Reading Papyri, Writing Ancient History, London: Routledge.

Bagnall, R. and Frier, B. (1994) The Demography of Roman Egypt, Cambridge: Cambridge University Press.

Boak, A.E. (1926) "Irrigation and Population in the Fayum, the Garden of Egypt," Geographical Review 16.3.

Boak, A.E. (1933) Papyri from Tebtunis i.

Boak, A.E. (1955) "The Population of Roman and Byzantine Karanis," Historia 4.

Boak, A. E., \& Peterson, E. E. (1931). Karanis: Topographical and Architectural Report of Excavations During the Seasons 1924-28. Ann Arbor: University of Michigan Press.

Bowman, A.K. (1991) "Literacy in the Roman Empire: Mass and mode," in J. Humphrey (ed.) Literacy in the Roman World, Journal of Roman Archaeology Supplementary Series, no. 9, Ann Arbor.

Cotton, H.M., Cockle, W.E.H., and Millar, F.G.B (1995) "The papyrology of the Roman Near East: a survey", JRS 85. 
Connolly, J., \& Lake, M. (2006). Geographical Information Systems in Archaeology. Cambridge: Cambridge University Press.

Gagos, T., Gates, J., \& Wilburn, A. (2005). "Material Culture and Texts of Graeco-Roman Egypt: Creating Context, Debating Meaning." Bulletin for the American Society of Papyrologists , 42.

Gazda, E.K. (1978) Guardians of the Nile: Sculptures from Karanis in the Fayoum (c.250 BC - AD 450), Ann Arbor.

Gazda, E.K. and Wilfong, T. (2005) Karanis: An Egyptian Town in Roman Times, Ann Arbor.

Grenfell, B. P., Hunt, A. S., Hogarth, D. G., \& Milne, J. G. (1900). Fayum Towns and their Papyri. London: Egypt Exploration Fund.

Haatvedt R.A. and E.E. Peterson. (1964) Coins from Karanis: the University of Michigan Excavations, 1924-1935, ed. E.M. Husselman, Ann Arbor 1964.

Harden, D.L. (1936) Roman Glass from Karanis Found by the University of Michigan Archaeological Expedition in Egypt 1924-29, Ann Arbor.

Harris, W.V. (1989) Ancient Literacy. Harvard University Press: Cambridge.

Husselman, E. M. (1971). Papyri from Karanis, Third Series (Michigan Papyri, Vol. IX). American Philological Association.

Husselman, E.M. (1979) Karanis Excavations of the University of Michigan in Egypt 1928-1935: A Summary of the Reports of the Director, Enoch E. Peterson, Ann Arbor. 
Johnson, A.C. (1936) "Wages," in ESAR ii.

Johnson, B. (1981) Pottery from Karanis: Excavations of the University of Michigan, Ann Arbor.

MacMullen, R. (1982) "The Epigraphic Habit in the Roman Empire," in the American Journal of Philology, 103.

Mueller, K. (2005). “Geographical Information Systems

(GIS) in Papyrology. Mapping Fragmentation and Migration Flow to Hellenistic Egypt." Bulletin for the American Society of Papyrologists , 42.

Meyer, E. (1990) "Explaining the Epigraphic Habit in the Roman Empire: The Evidence of Epitaphs," Journal of Roman Studies, Vol. 80.

Petrie, W.F. (1892) Ten Years of Digging in Egypt: 18811891, London: The Religious Tract Society.

Pomeroy, S. B. (1988) "Women in Roman Egypt. A

Preliminary Study based on Papyri," ANRW II 10.1 (1988) 708-723 = Reflections of Women in Antiquity, ed. H. Foley.

Scheidel, W. (2001) Death on the Nile: Disease and Demography of Roman Egypt. Leiden: Brill.

Shier, L.A. (1978) Terracotta Lamps from Karanis, Egypt: Excavations of the University of Michigan, Ann Arbor.

Stephan, R.P. (2005) The House of Claudius Tiberianus: Integrating Archaeology and Papyrology. Honors Thesis, University of Michigan - Ann Arbor. Unpublished.

Stephan, R.P. and A. Verhoogt (2005) "Text and Context in the Archive of Tiberianus (Karanis, Egypt; 2 ${ }^{\text {nd }}$ Century AD)." In Bulletin of the American Society of Papyrologists 42.

Past Imperfect 16 (2010) | ( ) | ISSN 1711-053X | elSSN 1718-4487 
van Minnen, P. (1993) "The Century of Papyrology (18921992)," in the Bulletin of the American Society of Papyrologists 30. pp. 5-18.

-------.(1994a) "House-to-House Enquiries: An Interdisciplinary Approach to Roman Karanis." in Zeitschrift für Papyrologie und Epigraphik 100: pp. 227-251.

-,(1994b) "The Origin and Future of Papyrology: From Mommsen and Wilamowitz to the Present, from Altertumwissenschaft to Cultural Studies," in Proceedings of the 20 th International Congress of Papyrologists (Copenhagen, 23-29 August 1992). Copenhagen: Museum Tusculanum Press.

Westermann, W.L. (1917) "Land Reclamation in the Fayum under the Ptolemies Philadelphus and Euergetes I," Classical Philology 12.

Wheatley, D., \& Gillings, M. (2002). Spatial Technology and Archaeology: The archaeological applications of GIS. London: Taylor and Francis.

Youtie, H.C. (1966) "Text and Context in Transcribing Papyri," GRBS 7.

-------, (1971) "Agrammatos: An Aspect of Greek Society in Egypt," Harvard Studies in Classical Philology 75.

Youtie, H. C., \& Pearl, O. M. (1944). Papyri and Ostraca from Karanis (Michigan Papyri, Vol. VI). Ann Arbor: University of Michigan Press.

Youtie, H. C., Schuman, V. B., \& Pearl, O. M. (1936-1939). Tax Rolls from Karanis in Two Volumes (Michigan Papyri, Vol. IV, Part I-II). Ann Arbor: University of Michigan Press. 
Youtie, H.C. and J.G. Winter. (1951) Papyri and Ostraca from Karanis, Second Series, Michigan Papyri Volume VIII, Ann Arbor. 